\title{
Effect of Foliar Application of Plant Growth Regulators and Nutrients on Quality of Kinnow Mandarin
}

\author{
Pooja*, R. P. S. Dalal, Reetika and Poonam Saini \\ Department of Horticulture CCSHAU, Hisar-125004, India \\ *Corresponding author
}

Ke y w or d s
Kinnow, nutrients,
$2,4-\mathrm{D}, \mathrm{GA}_{3}$
Article Info
Accepted:
$\begin{aligned} & 18 \text { May } 2020 \\ & \text { Available Online: } \\ & \text { 10 June } 2020\end{aligned}$

A B S T R A C T
The present study was undertaken to observe the response of Kinnow Mandarin to different forms of growth regulators and nutrients. The result of investigation indicates that fruit length and diameter were found maximum with the foliar application of $\mathrm{K}_{2} \mathrm{SO}_{4} 2 \%$, shape index and ascorbic acid were found maximum with the foliar application of 2, 4-D 20 ppm, peel thickness, acidity, peel content were recorded minimum and juice content and TSS were recorded maximum with the foliar application 2, 4-D $10 \mathrm{ppm}$, while rag content was found maximum with the application of $\mathrm{GA}_{3} 20 \mathrm{ppm}$. The total sugar was found maximum in fruits treated with treatment $\mathrm{K}_{2} \mathrm{SO}_{4} 2 \%$ while reducing sugar was found maximum under the treatment $\mathrm{K}_{2} \mathrm{SO}_{4} 1.5 \%$.

\section{Introduction}

In India, citrus fruits rank third in production after banana and mango. Among citrus crops, mandarin (Kinnow mandarin, Nagpur, Khasi and Darjling) covers largest area followed by sweet orange (Musambi, Pineapple, Blood Red and Jaffa) and Acid lime. Among these, Kinnow mandarin bears highest place in production, productivity, juice content and fruit quality. Foliar application of $\mathrm{Zn}$ and $\mathrm{K}$ improved $\mathrm{N}, \mathrm{P}, \mathrm{K}$ and $\mathrm{Zn}$ level in Washington Navel leaves (Hafez and El-Metwally, 2007) and effectively controlled fruit drop, increased yield, juice volume, total soluble solids and vitamin $\mathrm{C}$ in Kinnow mandarin (Ashraf et al., 2012). Foliar application of different levels of $\mathrm{GA}_{3}$ (5, 50,100 and $500 \mathrm{mg} \mathrm{L}^{-1}$ ) to young fruitlets just after fruit set has been reported to increase fruit weight and to reduce peel thickness and better recovery percentage with improved taste of grapefruit (Berhow, 2000).

As compared to other macronutrients, citrus fruit tree takes up higher amount of potassium (Alva \& Tucker, 1999; Ashraf et al., 2010; 2012). 
It has a key role in many physiological processes like water relations, opening and closing of stomata, cell division, formation of sugars and starch, neutralization of organic acids, synthesis of proteins, and activation of enzymes(Liu et al., 2000; Srivastava \& Singh, 2006).

By enhancing fruit size, juice contents, color, size and juice flavor potassium improves the fruit quality (Tiwari, 2005; Ashraf et al., 2010).

\section{Materials and Methods}

The present study was carried out at Chaudhary Farm House, Village Malapur, Hisar. Thirty-nine trees of uniform size and plant vigour with spacing $6 \times 6 \mathrm{~m}$ were selected. All the thirteen treatments were replicated three times taking one plant as a single unit. The treatments comprising of 2,4D ppm, $\mathrm{GA}_{3}, \mathrm{~K}_{2} \mathrm{SO}_{4}$ and $\mathrm{ZnSO}_{4}$ along with control were laid out in randomized block design.

\begin{tabular}{|l|c|c|}
\hline Sr. no. & Treatments & $\begin{array}{c}\text { Concentration of plant growth regulators } \\
\text { and nutrients for foliar application }\end{array}$ \\
\hline $\mathbf{1}$ & $\mathbf{T}_{\mathbf{1}}$ & $2,4-\mathrm{D} 10 \mathrm{ppm}$ \\
\hline $\mathbf{2}$ & $\mathbf{T}_{\mathbf{2}}$ & $2,4-\mathrm{D} 15 \mathrm{ppm}$ \\
\hline $\mathbf{3}$ & $\mathbf{T}_{\mathbf{3}}$ & $2,4-\mathrm{D} 20 \mathrm{ppm}$ \\
\hline $\mathbf{4}$ & $\mathbf{T}_{\mathbf{4}}$ & $\mathrm{GA}_{3} 10 \mathrm{ppm}$ \\
\hline $\mathbf{5}$ & $\mathbf{T}_{\mathbf{5}}$ & $\mathrm{GA}_{3} 15 \mathrm{ppm}$ \\
\hline $\mathbf{6}$ & $\mathbf{T}_{\mathbf{6}}$ & $\mathrm{GA}_{3} 20 \mathrm{ppm}$ \\
\hline $\mathbf{7}$ & $\mathbf{T}_{\mathbf{7}}$ & $\mathrm{K}_{2} \mathrm{SO}_{4} 1.0 \%$ \\
\hline $\mathbf{8}$ & $\mathbf{T}_{\mathbf{8}}$ & $\mathrm{K}_{2} \mathrm{SO}_{4} 1.5 \%$ \\
\hline $\mathbf{9}$ & $\mathbf{T}_{\mathbf{9}}$ & $\mathrm{K}_{2} \mathrm{SO}_{4} 2.0 \%$ \\
\hline $\mathbf{1 0}$ & $\mathbf{T}_{\mathbf{1 0}}$ & $\mathrm{ZnSO}_{4} 0.25 \%$ \\
\hline $\mathbf{1 1}$ & $\mathbf{T}_{\mathbf{1 1}}$ & $\mathrm{ZnSO}_{4} 0.50 \%$ \\
\hline $\mathbf{1 2}$ & $\mathbf{T}_{\mathbf{1 2}}$ & $\mathrm{ZnSO}_{4} 0.75 \%$ \\
\hline $\mathbf{1 3}$ & $\mathbf{T}_{\mathbf{1 3}}$ & $\mathrm{Control}$ \\
\hline
\end{tabular}

Fruit length (mm), fruit diameter(mm)and peel thickness $(\mathrm{mm})$ of four randomly selected fruits were measured with the help of digital Vernier Calipers.

\section{Fruit shape index}

Fruit shape index can be calculated by dividing fruit diameter with fruit height.

\section{Peel content $(\%)$}

For peel content four randomly selected fruits were peeled manually. The percent peel content was calculated by using the formula:

Peel content $(\%)=\frac{\text { Peel weight }}{\text { Fruit weight }} \times 100$ 


\section{Rag content (\%)}

$$
\text { Rag content }(\%)=\frac{[\text { Fruit weight }-(\text { Peel weight }+ \text { Juice weight })]}{\text { Fruit weight }} \times 100
$$

\section{Juice content (\%)}

The percent juice content was calculated by using the formula:

$$
\text { Juice content }(\%)=\frac{\text { Total juice weight }}{\text { Total weight of fruits }} \times 100
$$

\section{TSS ( ${ }^{0}$ brix $)$}

The TSS of the representative fruit juice was determined with the help of digital hand refractometer

\section{Acidity (\%)}

The acidity was estimated by titrating the juice with $0.1 \mathrm{~N} \mathrm{NaOH}$ using phenolpthalein as an indicator.

\section{Ascorbic acid(mg/100 ml of juice)}

Ascorbic acid was estimated as per the method given by AOAC (1990). Two ml of fruit juice was mixed with $2 \mathrm{ml}$ of $3 \%$ metaphosphoric acid as buffer and titrated with 2,6-dichlorophenol indophenol dye until the light pink colour appeared. The results were expressed as $\mathrm{mg}$ of ascorbic acid per $100 \mathrm{~g}$ of juice.

\section{Results and Discussion}

\section{Physical parameters}

The data recorded in Table 1 indicate that the application of different concentrations of 2,4$\mathrm{D}, \mathrm{GA}_{3}, \mathrm{~K}_{2} \mathrm{SO}_{4}$ and $\mathrm{ZnSO}_{4}$ influenced the fruit length, fruit diameter and shape index significantly. The maximum fruit length was found in treatment $\mathrm{T}_{9^{-}} \mathrm{K}_{2} \mathrm{SO}_{4} \quad 2 \% \quad(62.85$ $\mathrm{mm}$ )and minimum fruit length was found in control $(54.92 \mathrm{~mm})$. The fruit diameter was observed maximum in treatment $\mathrm{T}_{9-}-\mathrm{K}_{2} \mathrm{SO}_{4}$ $2 \%(71.81 \mathrm{~mm})$ while it was observed minimum in control $(63.37 \mathrm{~mm})$. Malik et al., (2000), Ashraf et al., (2012) and Razzaq et al., (2013) observed maximum fruit size in Kinnow mandarin with foliar application of $\mathrm{SA}+\mathrm{Zn}+\mathrm{K}$.

The shape index was found maximum under the treatment $\mathrm{T}_{3}-2$, 4-D $20 \mathrm{ppm}$ (0.87). The shape index was found minimum under control (0.81).

The data in Table 2 shows the significant influence of different concentrations of 2, 4$\mathrm{D}, \mathrm{GA}_{3}, \mathrm{~K}_{2} \mathrm{SO}_{4}$ and $\mathrm{ZnSO}_{4}$ on juice content, rag content and peel content in Kinnow mandarin fruit. The juice content was observed maximum in treatment $\mathrm{T}_{1^{-}} 2$, 4-D 10 ppm $(49.75 \%)$ and minimum juice content was observed in treatment $\mathrm{T}_{9^{-}} \mathrm{K}_{2} \mathrm{SO}_{4} 2 \%$ $(45.65 \%)$.

The rag content was obtained minimum in treatment $\mathrm{T}_{12^{-}} \quad \mathrm{ZnSO}_{4} \quad 0.5 \%(24.77 \%)$ and maximum in treatment $\mathrm{T}_{6^{-}} \mathrm{GA}_{3} \quad 20$ ppm(27.30\%). Sangwan et al., (2008) observed that rag content was found nonsignificant but it increased with all the potassium treatments.

The treatment $\mathrm{T}_{1^{-}}$2, 4-D $10 \mathrm{ppm}(25.33 \%)$ showed the minimum peel content while the treatment $\mathrm{T}_{9}-\mathrm{K}_{2} \mathrm{SO}_{4} 2 \%(27.93 \%$ ) showed the maximum peel content. Kaur et al., (2000) investigated the effect of $\mathrm{GA}_{3} 15$ and $20 \mathrm{ppm}$, 2,4-D 20 ppm, NAA 20 ppm and urea 1\% on peel content of Kinnow mandarin fruit and found the minimum peel content in fruits under the treatment 2, 4-D 20 ppm (26.3\%) and maximum in fruits of control treatment (30.3\%). The treatment $\mathrm{T}_{1}-2,4-\mathrm{D} 10 \mathrm{ppm}$ 
$(3.46 \mathrm{~mm})$ showed the minimum peel thickness in Kinnow mandarin while the treatment $\mathrm{T}_{13^{-}}$Control $(4.13 \mathrm{~mm})$ showed the maximum peel thickness. The results of present study are in conformity with Sharma et al., (2013) who observed the minimum peel thickness $(3.41 \mathrm{~mm})$ in fruits taken from the plants sprayed with 2, 4-D $30 \mathrm{ppm}$ and maximum $(5.33 \mathrm{~mm})$ in control fruits.

\section{Chemical parameters}

The data in Table 3 shows the significant influence of different concentrations of 2, 4$\mathrm{D}, \mathrm{GA}_{3}, \mathrm{~K}_{2} \mathrm{SO}_{4}$ and $\mathrm{ZnSO}_{4}$ on TSS, acidity and ascorbic acid. The TSS was reported maximum in treatment $\mathrm{T}_{9}-\mathrm{K}_{2} \mathrm{SO}_{4} 2 \%(11.4$ ${ }^{0}$ brix) and minimum in treatment $\mathrm{T}_{1}-2,4-\mathrm{D}$ $10 \operatorname{ppm}\left(9.8^{0}\right.$ brix $)$. The results of present study are in conformity with the findings of Ashraf et al., (2011) who found an increase in TSS in citrus juice with foliar application of $\mathrm{Zn}+\mathrm{K}$. The increase in TSS content with foliar application of $\mathrm{K}$ was related with the role of potassium in translocation of sugars from leaves to fruits (Havlin et al., 2007).

The acidity was found minimum in treatment $\mathrm{T}_{1^{-}} \quad 2$ 2, 4-D $10 \quad \operatorname{ppm}(0.75 \%)$, whereas maximum acidity was found in treatment $\mathrm{T}_{9}$ $\mathrm{K}_{2} \mathrm{SO}_{4} 2 \%(0.93 \%)$. Saleem et al., (2008) found that the acidity in juice of Blood Red oranges increased significantly with the increase in 2, 4-D concentration.

The maximum ascorbic acid was observed in treatment $\mathrm{T}_{3}$ - 2, 4-D $20 \mathrm{ppm}(29.70 \mathrm{mg} / 100$ $\mathrm{ml}$ ) while minimum in treatment $\mathrm{T}_{5}-\mathrm{GA}_{3} 15$ ppm (26.8). The results of present study are in conformity with the findings of Maurya et al., (1973) who observed that with the application of 2, 4-D $20 \mathrm{ppm}$ ascorbic acid content increased in Dusehri mango. The data in Table 4 shows the significant influence of different concentrations of 2, 4-D, $\mathrm{GA}_{3}$, $\mathrm{K}_{2} \mathrm{SO}_{4}$ and $\mathrm{ZnSO}_{4}$ on total and reducing sugar. The maximum total sugar was found in fruits treated with treatment $\mathrm{T}_{9}-\mathrm{K}_{2} \mathrm{SO}_{4} 2 \%$ $(10.10 \%)$, whereas minimum total sugar was found in fruits of control (8.78\%).

The increase in the content of total sugars in fruits might be due to degradation of polysaccharides into simple sugars by the enzymes, conversion of organic acids into sugars and loss of moisture from the fruits (Kumar et al., 2011). The results of the present study are in conformity with the findings of Khan et al., (2015) who found that the total sugars could be improved with exogenous application of nutrients ( $\mathrm{Zn}$ and $\mathrm{K}$ ) in Kinnow mandarin. The maximum total and reducing sugars increased with all the potassium treatments in Kinnow mandarin (Sangwan et al., 2008).

The reducing sugar was found maximum under the treatment $\mathrm{T}_{8}-\mathrm{K}_{2} \mathrm{SO}_{4} 1.5 \%$ (4.03\%). The reducing sugar was found minimum under $\mathrm{T}_{10}-\mathrm{ZnSO}_{4} 0.25 \%$ (3.31\%). However, Ram and Bose (2000) concluded that the foliar application of micronutrients (zinc, boron and Manganese) had no effect on reducing and non-reducing sugars in mandarin and sweet orange, respectively.

The effect of different concentrations of 2, 4$\mathrm{D}, \mathrm{GA}_{3}, \mathrm{~K}_{2} \mathrm{SO}_{4}$ and $\mathrm{ZnSO}_{4}$ was found nonsignificant on non-reducing sugar. However, the maximum non-reducing sugar was found in treatment $\mathrm{T}_{3}-2$, 4-D $20 \mathrm{ppm}$ (5.23\%) and minimum non-reducing sugar was found in control $(5.54 \%)$. The results of the present study are in conformity with the findings of Jadhavar et al., (1991) who recorded a significant increase in non-reducing sugar content of Nagpur Santra fruits with 2, 4-D applied at $15 \mathrm{ppm}$. Wang et al., (2004) recorded that the sugar content could be increased with the application of 2, 4-D, $\mathrm{GA}_{3}$ and some other growth regulators in fruits of various mandarin and sweet orange cultivars. 
Table.1 Effect of different plant growth regulators and nutrients on length $(\mathrm{mm})$, diameter $(\mathrm{mm})$ and shape index in Kinnow mandarin fruit

\begin{tabular}{|c|c|c|c|}
\hline \multirow[t]{2}{*}{ Treatments } & \multicolumn{2}{|c|}{ Fruit size (mm) } & \multirow[b]{2}{*}{ Shape index } \\
\hline & Fruit length (mm) & Fruit diameter (mm) & \\
\hline$T_{1}: 2,4-D 10$ ppm & 55.12 & 64.34 & 0.84 \\
\hline$T_{2}: 2,4-D 15$ ppm & 57.82 & 66.71 & 0.84 \\
\hline $\mathrm{T}_{3}: 2,4-\mathrm{D} 20 \mathrm{ppm}$ & 56.23 & 65.63 & 0.87 \\
\hline $\mathrm{T}_{4}: \mathbf{G A}_{3} 10 \mathrm{ppm}$ & 56.29 & 65.23 & 0.83 \\
\hline$T_{5}: G_{3} 15$ ppm & 59.22 & 68.83 & 0.82 \\
\hline$T_{6}: G A_{3} 20$ ppm & 59.63 & 68.74 & 0.84 \\
\hline $\mathrm{T}_{7}: \mathrm{K}_{2} \mathrm{SO}_{4} 1.0 \%$ & 60.04 & 69.23 & 0.82 \\
\hline $\mathrm{T}_{8}: \mathrm{K}_{2} \mathrm{SO}_{4} 1.5 \%$ & 60.41 & 69.88 & 0.82 \\
\hline $\mathrm{T}_{9}: \mathrm{K}_{2} \mathrm{SO}_{4} 2.0 \%$ & 62.85 & 71.81 & 0.82 \\
\hline $\mathrm{T}_{10}: \mathrm{ZnSO}_{4} \mathbf{0 . 2 5 \%}$ & 55.93 & 64.78 & 0.82 \\
\hline $\mathrm{T}_{11}: \mathrm{ZnSO}_{4} \mathbf{0 . 5 0 \%}$ & 58.43 & 67.89 & 0.84 \\
\hline $\mathrm{T}_{12}: \mathrm{ZnSO}_{4} \mathbf{0 . 7 5 \%}$ & 58.29 & 67.45 & 0.84 \\
\hline $\mathbf{T}_{13}:$ Control & 54.92 & 63.37 & 0.81 \\
\hline CD at $5 \%$ level of significance & 1.57 & 4.28 & 0.01 \\
\hline
\end{tabular}

Table.2 Effect of plant growth regulators and nutrients on juice, peel and rag content (\%) in Kinnow mandarin fruit

\begin{tabular}{|c|c|c|c|c|}
\hline \multirow[t]{2}{*}{ Treatments } & \multicolumn{3}{|c|}{ Content (\%) } & \multirow{2}{*}{$\begin{array}{l}\text { Peel thickness } \\
(\mathbf{m m})\end{array}$} \\
\hline & Juice & Rag & Peel & \\
\hline$T_{1}: 2,4-D 10$ ppm & 49.75 & 24.92 & 25.33 & 3.46 \\
\hline$T_{2}: 2,4-D 15$ ppm & 48.52 & 26.05 & 25.43 & 3.58 \\
\hline$T_{3}: 2,4-D 20 \mathrm{ppm}$ & 48.00 & 26.13 & 25.87 & 3.69 \\
\hline$T_{4}: G_{3} 10$ ppm & 47.83 & 26.07 & 26.10 & 3.74 \\
\hline $\mathrm{T}_{5}: \mathbf{G A}_{3} 15 \mathrm{ppm}$ & 46.53 & 27.15 & 26.32 & 3.77 \\
\hline$T_{6}: G_{3} 20$ ppm & 45.90 & 27.30 & 26.80 & 3.85 \\
\hline $\mathrm{T}_{7}: \mathrm{K}_{2} \mathrm{SO}_{4} 1.0 \%$ & 47.80 & 24.92 & 27.28 & 3.98 \\
\hline $\mathrm{T}_{8}: \mathrm{K}_{2} \mathrm{SO}_{4} 1.5 \%$ & 47.23 & 24.89 & 27.88 & 4.00 \\
\hline $\mathrm{T}_{9}: \mathrm{K}_{2} \mathrm{SO}_{4} 2.0 \%$ & 45.65 & 26.42 & 27.93 & 4.04 \\
\hline $\mathrm{T}_{10}: \mathrm{ZnSO}_{4} 0.25 \%$ & 49.33 & 25.19 & 25.48 & 3.53 \\
\hline $\mathrm{T}_{11}: \mathrm{ZnSO}_{4} 0.50 \%$ & 48.15 & 25.27 & 26.58 & 3.63 \\
\hline $\mathrm{T}_{12}: \mathrm{ZnSO}_{4} 0.75 \%$ & 47.80 & 24.77 & 27.43 & 3.82 \\
\hline $\mathbf{T}_{13}$ : Control & 48.56 & 25.86 & 25.58 & 4.13 \\
\hline $\begin{array}{l}\text { CD at } 5 \% \text { level of } \\
\text { significance }\end{array}$ & 1.02 & 0.78 & 0.72 & 0.21 \\
\hline
\end{tabular}


Table.3 Effect of plant growth regulators and nutrients on TSS $\left({ }^{0}\right.$ brix $)$, acidity (\%) and ascorbic acid $(\mathrm{mg} / 100 \mathrm{ml})$ in Kinnow mandarin fruit

\begin{tabular}{|c|c|c|c|}
\hline Treatments & TSS $\left({ }^{0}\right.$ brix $)$ & Acidity (\%) & $\begin{array}{c}\text { Ascorbic acid } \\
\text { (mg/100ml juice) }\end{array}$ \\
\hline $\mathrm{T}_{1}:$ 2,4-D $10 \mathrm{ppm}$ & 9.8 & 0.75 & 28.52 \\
\hline$T_{2}:$ 2,4-D 15 ppm & 10.0 & 0.77 & 29.00 \\
\hline$T_{3}: 2,4-D 20$ ppm & 10.2 & 0.81 & 29.70 \\
\hline$T_{4}: G_{3} 10$ ppm & 10.2 & 0.83 & 27.52 \\
\hline$T_{5}: G_{3} 15$ ppm & 10.6 & 0.89 & 26.87 \\
\hline$T_{6}: G_{3} 20$ ppm & 11.0 & 0.92 & 28.36 \\
\hline $\mathrm{T}_{7}: \mathrm{K}_{2} \mathrm{SO}_{4} 1.0 \%$ & 10.8 & 0.90 & 27.00 \\
\hline $\mathrm{T}_{8}: \mathrm{K}_{2} \mathrm{SO}_{4} 1.5 \%$ & 11.0 & 0.91 & 27.41 \\
\hline $\mathrm{T}_{9}: \mathrm{K}_{2} \mathrm{SO}_{4} 2.0 \%$ & 11.4 & 0.93 & 28.00 \\
\hline $\mathrm{T}_{10}: \mathrm{ZnSO}_{4} 0.25 \%$ & 9.8 & 0.76 & 27.92 \\
\hline $\mathrm{T}_{11}: \mathrm{ZnSO}_{4} \mathbf{0 . 5 0 \%}$ & 10.0 & 0.79 & 28.72 \\
\hline $\mathrm{T}_{12}: \mathrm{ZnSO}_{4} 0.75 \%$ & 10.4 & 0.85 & 29.49 \\
\hline $\mathbf{T}_{13}:$ Control & 10.0 & 0.75 & 27.41 \\
\hline CD at $5 \%$ level of significance & $\mathbf{0 . 8 0}$ & 0.11 & 2.00 \\
\hline
\end{tabular}

Table.4 Effect of plant growth regulators and nutrients on percent sugar in Kinnow mandarin fruit

\begin{tabular}{|c|c|c|c|}
\hline \multirow[t]{2}{*}{ Treatments } & \multicolumn{3}{|c|}{ Sugars (\%) } \\
\hline & Reducing & Non-reducing & Total sugar \\
\hline $\mathrm{T}_{1}: 2,4-\mathrm{D} 10 \mathrm{ppm}$ & 3.63 & 5.17 & 8.80 \\
\hline$T_{2}: 2,4-D 15$ ppm & 3.73 & 5.22 & 8.95 \\
\hline$T_{3}: 2,4-D 20 \mathrm{ppm}$ & 3.87 & 5.23 & 9.10 \\
\hline$T_{4}: G_{3} 10$ ppm & 3.60 & 5.58 & 9.18 \\
\hline$T_{5}: G_{3} 15$ ppm & 3.32 & 6.45 & 9.77 \\
\hline$T_{6}: G_{3} 20 \mathrm{ppm}$ & 3.86 & 5.84 & 9.70 \\
\hline $\mathrm{T}_{7}: \mathrm{K}_{2} \mathrm{SO}_{4} 1.0 \%$ & 3.85 & 5.15 & 9.00 \\
\hline $\mathrm{T}_{8}: \mathrm{K}_{2} \mathrm{SO}_{4} 1.5 \%$ & 4.03 & 5.90 & 9.93 \\
\hline $\mathrm{T}_{9}: \mathrm{K}_{2} \mathrm{SO}_{4} 2.0 \%$ & 3.92 & 6.18 & 10.10 \\
\hline $\mathrm{T}_{10}: \mathrm{ZnSO}_{4} 0.25 \%$ & 3.31 & 5.64 & 8.95 \\
\hline $\mathrm{T}_{11}: \mathrm{ZnSO}_{4} \mathbf{0 . 5 0 \%}$ & 3.34 & 5.90 & 9.24 \\
\hline $\mathrm{T}_{12}: \mathrm{ZnSO}_{4} \mathbf{0 . 7 5 \%}$ & 3.97 & 5.61 & 9.58 \\
\hline$T_{13}$ : Control & 3.36 & 5.44 & 8.78 \\
\hline CD at $5 \%$ level of significance & 0.44 & N/S & 1.10 \\
\hline
\end{tabular}


The present research findings indicate that foliar application of 2,4-D 10 and $20 \mathrm{ppm}$ are effective in improving juice quality by increasing juice volume, Total soluble solids, acidity and ascorbic acid content. Sugar content can be increased with the foliar application of $\mathrm{K}_{2} \mathrm{SO}_{4}$.

\section{Acknowledgement}

The authors thankfully acknowledge to CCS Haryana Agricultural University, Hisar for providing all the facilities to conduct this research experiment.

\section{References}

Alva, A.K. and D.P.H. Tucker. 1999. Soil and citrus nutrition. In: Citrus Health Management. (Eds.): L.W. Timmer and C.W. Duncan. Gainsville University of Florida, 6, 59-71.

Ashraf, M.Y., A. Gul, M. Ashraf, F. Hussain and G. Ebert. 2010. Improvement in yield and quality of Kinnow (Citrus deliciosa x Citrus nobilis) by potassium fertilization. Journal of Plant Nutrition, 33: 1625-1637.

Ashraf, M.Y., Hussain, F., Akhtar, J., Khan, M. and Ebert, G., 2011. Modulation in yield and juice quality characteristics of citrus fruit from trees supplied with zinc and potassium foliarly. Journal of Plant Nutrition, 34: 1996-2012.

Ashraf, M.Y., Yaqub, M., Akhtar, J., Khan, M.A., Ali-Khan, M. and Ebert, G., 2012.Control of excessive fruit drop and improvement in yield and juice quality of Kinnow (Citrus deliciosax Citrus nobilis) through nutrient management. Pakistan Journal of Botany, 44: 259265.

Berhow, M.A., 2000. Effect of early plant growth regulator treatments on flavonoid levels in grapefruit. Journal of Plant Growth Regulation, 30: 225-
232.

Hafez, O.M and El-Metwally, I.M., 2007.Efficiency of zinc and potassium spray alone or in combination with some weed control treatments on weed growth yield and fruit quality of Washington Navel oranges.Egyptian Journal of scientific Research, 3: 613621.

Havlin, J.L., Tisdale, S.L., Beaton, J.D. and Nelson, W.L., 2007. Soil Fertility and Fertilizers.An Introduction to Nutrient Management $\quad\left(7^{\text {th }}\right.$ Edn. $), \quad$ Dorling Kindersley Pvt. Ltd., India, pp. 196216.

Jadhavar, V.T., Jature, S.D., Jogdand, S.D. and Ankush, G.S., 1991. Effect of growt $h$ regulators on physic chemical composition of Nagpur santra $(C$. reticulate Blanco). Horticulture Journal, 4(2): 23-25.

Kaur, N., Monga, P.K., Thatai, S.K. and Vij, V.K., 2000. Effect of growth regulators on periodical fruit drop in Kinnow mandarin. Haryana Journal of Horticultural Sciences, 29(1and2): 3941.

Khan, A.S., Nasir, M., Malik, A.U., Basra S.M.A. and Jaskani, M.J., 2015. Combined application of boron and zinc influence the leaf mineral status, growth, productivity and fruit quality of Kinnow mandarin. Journal of Plant Nutrition, 38: 821-838.

Kumar, S., Singh, A.K. and Singh, A., 2011.Effect of foliar application of various growth regulators nutrients on shelf life and chemical attributes of guava cv.Lucknow-49.Plant Archives, 11: 107-111.

Liu, K., F. Huihua, B. Qixin and S. Luan. 2000. Inward potassium channel in guard cells as a target for polyamine regulation of stomatal movements. Plant Physiol., 124: 1315-1326.

Malik, R.P., Ahlawat, V.P and Nain, A.S., 
2000. Effect of foliar spray of urea and zinc sulphate on yield and fruit quality of Kinnow-a mandarin hybrid.Haryana Journal of Horticultural Sciences, 29(1/2): 37-38.

Maurya, A.N., Singh, S.M. and Singh, A.R., 1973. Effect of plant growth regulators on fruit retention and quality of Dusehri mango. Punjab Journal of Horticulture, 13: 117-121.

Ram, R.A. and Bose, T.K., 2000. Effect of foliar application of magnesium and micro-nutrients on growth, yield and fruit quality of mandarin orange (Citrus reticulate Blanco).Indian Journal of Horticulture, 57: 215-220.

Razzaq, K., Khan, A.S., Malik, A.U., Shahid, M. and Ullah, S., 2013. Foliar application of zinc influences the leaf mineral status, vegetative and reproductive growth, yield and fruit quality of Kinnow mandarin (Citrus reticulate Blanco.). Journal of Plant Nutrition, 36: 1479-1495.

Saleem, B.A., Malik, A.U. and Farooq, M., 2008. Spring application of growth regulators affects fruit quality of Blood Red sweet orange. Pakistan Journal of Botany, 40: 1013-1023.

Sangwan, A.K., Rattanpal, H.S., Arora, N.K. and Dalal, R.S., 2008.Effect of foliar application of potassium on fruit yield and quality of Kinnow mandarin. Environment and Ecology, 26(4): 23152318.

Sharma, M.K., Chaudhary, H.D., Jain, M.C. and Bhatnagar, P., 2013. Effect of plant growth regulators on growth and yield of Nagpur Mandarin (Citrus reticulate Blanco).The Asian Journal of Horticulture, 8: 746-750.

Sheoran, O.P., Tonk, D.S., Kaushik, L.S., Hasija, R.C., Pannu, R.S.: Statistical Software Package for Agricultural Research Workers Recent Advances in information theory, Statistics and Computer Applications by D.S. Hooda and R.S. Hasija, Department of Mathematics \& Statistics, CCSHAU, Hisar. 1998; 139-143.

Srivastava, A.K. and S. Singh. 2006. Zn nutrition, a global concern of sustainable citrus production. Journal of Sustainable Agriculture, 24: 5-42.

Tiwari, K.N. 2005. Diagnosing potassium deficiency and maximizing fruit crop production. Better Crop, 89: 29-31.

Wang, C.F., You, Y., Chen, F., Lu, X.S., Wang, J. and Wang, J., 2004.Adjusting effect of brassinolide and $\mathrm{GA}_{4}$ on the orange growth. Acta Agriculturae, 26(5): 759-762.

\section{How to cite this article:}

Pooja, R. P. S. Dalal, Reetika and Poonam Saini. 2020. Effect of Foliar Application of Plant Growth Regulators and Nutrients on Quality of Kinnow Mandarin. Int.J.Curr.Microbiol.App.Sci. 9(06): 1263-1270. doi: https://doi.org/10.20546/ijcmas.2020.906.156 